\title{
De jure, De facto Globalization and Economic Growth in Sub-Saharan Africa
}

\author{
Hodabalo BATAKA* \\ Université de Kara, Kara, Togo
}

\begin{abstract}
Using data from 40 Sub-Saharan African (SSA) countries from 1980 to 2015, the present study examines the effects of globalization and its dimensions on economic growth by distinguishing the de jure and de facto aspects. Through second-generation panel data tests, the study analyzes the crosssectional dependence between the countries studied and adopts an appropriate methodology for its effectiveness treatment. The study finds an economic growth effect for the overall globalization in SSA countries. It also demonstrates that de jure globalization increases economic growth, while de facto aspect undermines this growth. However, this is still evidence that de jure, de facto economic globalization, and de jure social globalization promote economic growth. De facto social globalization and de jure political globalization remain ineffective, while de facto political dimension of globalization hinders growth.
\end{abstract}

JEL Classification: C23, F43, O10, O55

Keywords: De jure globalization, De facto globalization, Economic growth, Crosssectional dependence, Panel data, Sub-Saharan Africa.

\footnotetext{
* Corresponding Author: Hodabalo BATAKA; Assistant Professor, Department of Economy, Université de Kara, B.P 43, 404, Kara, Togo. Tel: (00228) 93131379, E-mail: batakahodabalo8@gmail.com. 


\section{Introduction}

Globalization, characterized by international dependencies and interactions among individuals, has seen phenomenal growth over the past two decades, especially in the developing world. It is a multidimensional concept conceived as a process of creating networks of connections among actors at the intra- or multicontinental-level steam of capital, information, ideas, and images through facilitation of goods and people flows (Clark 2000, Norris 2000). It thus leads to formation of a single continent through erosion of national borders and integration of national economies, cultures, technologies, institutions, and governance and produces complex interdependencies (Dreher et al. 2008). Globalization that melts countries to the world will obviously affect economic growth of developing countries.

Globalization has affected both developed and developing countries. With regard to Sub-Saharan African (SSA) countries, one can historically identify the phenomenon of globalization in the 1980s with Structural Adjustment Policies (SAPs) instituted by the World Bank (BM) and Monetary Fund International (FM) to address the issues of payment balances experienced by the SSA countries. In fact, the uncompromising policies imposed by these international institutions forced these countries to open up to imports and foreign direct investment (FDI) (Schneider 2003, Ajayi 2003, Dreher 2006). These countries continue to experience economic globalization in other forms. SSA countries receive significant support from these international institutions, but these institutions continue to impose requirements of openness to capital and international trade. Participation in several international trade agreements also exposes these countries to external movements. Economic globalization of SSA countries since the 1980s has continues to the 1990s by another variant of globalization, called social globalization. Social globalization has gained momentum by the intensification of tourist and migratory flows in SSA countries, especially countries that abound in natural resources (UNWTO 2017). The direct friction of the SSA population with the foreigners can be a channel to share the way of life, cultures, values, and images between the two populations. In addition to direct contact with people, another aspect of social globalization emerged in SSA in the 2000s through sharing of information and images through communication channels. In fact, SSA countries have experienced the remarkable use of new information and communication technologies (NTCI), such as internet and mobile phone, that have taken over from the fixed telephone in information dissemination (Nyirenda-Jere and Biru 2015). These new means of communication allow the SSA countries to socially connect to the world. The information dissemination, especially related to government policies, is another form of globalization known as political globalization. This form can be expressed by the membership or the participation of countries in international organizations or missions. As the number of international organizations, non-governmental organizations, and international conventions owned or signed by SSA countries grow each year (Ibrahim 2013), the policies of these countries are deeply embedded in other countries and vice versa.

Globalization, hence, remains striking in its dimensions in SSA countries. It conditions macroeconomic variables movements or variations such as economic growth of these countries. Several theoretical and empirical works have focused on the association between 
globalization and economic growth. Pioneering theories have focused on economic globalization through trade integration and FDI. Optimistic theories in this area support trade integration as an engine of economic growth. Openness to international trade can generate economic growth by strengthening knowledge and technology diffusion through direct importation of high-technology products (Grossman and Helpman 1993, Barro and Sala-iMartin 1997, Baldwin et al. 2005, Almeida and Fernandes 2008). Openness to international trade also benefits from the potential gains associated with specializations and economies of scale (Alesina et al. 2000), and thus increases productivity and economic growth. From the economic perspective, the neoclassical growth model predicts that, on the basis of the differential return on capital, the latter will migrate from rich to poor economies. This flow of capital from rich countries can supplement the limited savings of the poor countries and reduce the cost of capital, which will lead to increased investment and in turn to economic growth. Financial globalization through the movement of FDI can be a source of technology transfer, managerial and organizational knowledge, and development research, especially from developed to developing countries (Borenszteina, De Gregoriob and Lee 1998, Bloomstrom 1992). This can increase the productivity of domestic firms and stimulate economic growth.

In addition to theories supporting economic globalization as an opportunity for economic growth, some studies arise from endogenous growth model postulating that globalization is detrimental to economic growth. Openness to trade could effectively hinder long-term growth if an economy specializes in sectors that are comparatively disadvantaged in terms of potential productivity growth or in sectors with depleted technological innovation (Redding 1999, Young 1991). Economic globalization can also have adverse effects on economic growth. Financial and unemployment crises can contribute negatively to economic growth of countries. The negative effects are also visible in the degradation of the environment through pollution.

Other studies show the importance of political and social globalization on growth. Political globalization allow the diffusion of the policies and institutions of national governments through international organizations, offer opportunities for consolidation of democracy and growth of good institutions, which are important factors for economic growth. Political globalization can also help in sharing experiences on aspects of human rights and maintenance of world peace, which are important for sustained economic growth. For pessimists, however, political globalization can be a source of conflict as well as of the emergence of egocentric leaders and groups with vested self-interest (Nahavandian and Ghanbari 2004). From this perspective, political globalization is seen as hurting economic growth. On the other hand, social globalization could be a basis for the development of citizenship rights and advancement of social status, leading to economic participation, public service, volunteer activities, and other social activities to improve the living conditions of all citizens, which in turn influence countries' economic growth (Majidi 2017).

There are several empirical studies on this subject. However, these works remain controversial with regard to effects of globalization on economic growth of. Some authors find that globalization and its aspects have positive effects on economic growth (Almas 
and Sangchoon 2010, Samimi and Jenatabadi 2014, Gurgul and Lach 2014, Egbetunde and Akinlo 2015, Olimpia and Stela 2017). However, a few others highlight a negative association between globalization, its indicators, and economic growth (Barry 2010, Musila and Yiheyis 2015). Empirical literature is mixed, either because of the indicators used to measure globalization and the methodological approaches implemented or because of the countries studied.

The present study analyzing the effects of globalization on economic growth in SSA countries differs from the existing literature in two key aspects: the spatial dependence between units (countries) analyzed and the interdependence (cross-sectional dependence) highlighted by spatial econometrics (LeSage and Pace 2009, Anselin et al. 2008, LeSage and Pace 2014) between units located in space. Therefore, suitable methodological approaches are needed to obtain unbiased and consistent estimators (Pesaran 2004, 2007, 2015, Chudik and Pesaran 2015). Moreover, economic growth is a spatial phenomenon (Rey 2001, Baumont et al. 2003). To obtain appropriate results, these spatial effects must be mastered. There are likely no earlier studies on globalization and economic growth in SSA countries that have proposed an adequate treatment of this cross-sectional dependence; therefore, the results obtained may be biased and inconsistent. The present study contributes to literature by classifying de jure and de facto globalization using KOF revised index of globalization. While measures of de facto globalization include variables that represent flows and activities, de jure measures include those that represent economic policies that, in principle, orient flows and activities (Gygli et al. 2018). This categorization uses de facto or de jure measures of globalization that lead to systematically different conclusions in the association between globalization and economic growth (Quinn et al. 2011). The distinction of de jure from de facto variables also helps in understanding the pragmatism of economic policies and institutions in the field of globalization.

Section 2 of this study presents some previous studies on globalization and economic growth, Section 3 discusses the methodological approach and the estimation strategy, Section 4 deals with variables description, results, and interpretation are presented in Section 5 and Section 6 concludes.

\section{Review on Globalization and Economic Growth}

Globalization can be understood through economic, social, and political approaches. The economics approach refers to the abolition of all obstacles against trade and capital liberalization, FDI, and portfolio investments and information related to these phenomena. The political approach is characterized by diffusion of government policies through participation of countries in international missions and/or their adhesion to international institutions. Social globalization, on the other hand, encompasses the dissemination of ideas, information, images, and cultures through telecommunications (landline and mobile phones, radios, and Internet) and people-to-people direct contacts (tourism, migration) (Dreher et al. 2008). Theories on globalization and economic growth show that globalization can be a 
source of technological diffusion arising from research and development and it can help to disseminate ideas, values, cultures of democracy, and respect for human rights and the quality of institutions that are important for economic growth (Romer 1990, Coe and Helpman 1995, Eaton and Kortum 1999, Meissner 2014). Some researchers claim that the effect of all these interactions on countries' economic growth still depend of their capacity to absorb new technologies and their institutional framework (Acemoglu et al. 2005, Meissner 2014). The effects of globalization on economic growth may therefore be asymmetrical, depending on whether the study focuses on developed or developing countries. This explains the lack of empirical literature.

Based on panel data, Dreher (2006) empirically analyzed whether the KOF index of globalization and its subindices (economic, social, and political) affect economic growth. His showed that globalization promotes economic growth. The dimensions most correlated to growth apply to the economic and social dimension in developed countries, while the political dimension has no effect. Gurgul and Lach (2014) found similar results. Researchers, however, highlight that social dimension of globalization, such as internet, television, and newspapers trade, has a positive impact on economic development. The economic dimension targets openness to international trade and foreign investment. Using KOF index of globalization, Rao and Vadlamannati (2011) examined the effects of globalization on economic growth in African countries. Based on the panel data from 21 low-income countries, the authors highlighted that the growth effects are weak, permanent, positive, and significant. They also underline that, unlike Levine and Renelt (1992), the long-run effects of globalization have proved to be robust. Kilic (2015) analyzes the relationship between globalization and economic growth using the KOF index, while distinguishing between economic, political, and social globalization. There are studies that focus on 71 countries from 1981 to 2011. Their results indicate that economic and political globalization has improved economic growth in some developing countries, while social globalization has hindered economic growth in some. Olimpia and Stela (2017) found similar results in their work conducted in Romania from 1990 to 2013. The association between globalization and economic growth is also analyzed by Majidi (2017) using the KOF index with a distinction between economic, political, and social globalization. A study was conducted in 100 countries from 1970 to 2014. Majidi (2017) found negative economic growth effects for political globalization in upper-middle-income countries, while economic and social globalization effects were not significant. Focusing on lower-middle-income developing countries, Majidi (2017) also found that political globalization increases economic growth but economic and social globalization does not affect economic growth in these countries. Using the generalized moment method (GMM), Samimi and Jenatabadi (2014) examined the association between economic globalization and economic growth in Organization for Economic Cooperation countries. They found that economic globalization measured by the KOF index promotes economic growth in high- and middle-income countries although it negatively affects lowincome countries. They specify that workforce level qualification and financial development system remain significant for economic growth effects of globalization. Hadiatou (2010) also discussed the association between globalization and economic growth in SSA countries. 
The study results show that globalization has a positive but insignificant impact on economic growth in SSA. However, it positively and significantly affects countries with limited natural resources.

Some authors analyze the association between globalization and economic growth using specific indicators such as FDI, trade openness, and official development assistance. Using the dynamic growth model, Zahonogo (2018) analyzed the relationship between trade openness (economic globalization) and economic growth in SSA. Based on the panel data, Zahonogo (2018) showed a nonlinear relationship between globalization and economic growth and endorsed SSA countries to control trade openness, especially imports of consumption goods in order to stimulate their economic growth. Egbetunde and Akinlo (2015) examined the effects of financial globalization on economic growth in SSA countries. Using panel error-correction model, the authors concluded that SSA economies will benefit from long-term financial globalization as governments promote sound macroeconomic policies and strong institutions. Musila and Yiheyis (2015) distinguished between overall trade openness (de facto globalization) and openness induced by trade policy (de jure globalization) to analyze the effects of globalization on growth in Kenya. They found that de facto globalization does not affect growth, while de jure globalization negatively affects economic growth in Kenya. Moghaddam and Redzuan (2012) used FDI to analyze the effects of globalization on economic development in developing countries. Their study led to the conclusion that attraction of FDI supports economic growth. Borensztein et al. (1998) found similar results in their work on 69 developing countries. Khaliq and Noy (2007), on the other hand, found that aggregate FDI has a positive impact on Indonesia's economic growth, while sectorial analysis reveals the negative effects of FDI targeting the mining sector. The present study complements the existing literature by adopting a methodological approach to solve cross-sectional dependence problem and by making a perfect distinction between de facto and de jure globalization in the context of SSA countries.

\section{Methodology and Estimation Strategy}

The methodological approach in the present study is based on the augmented neoclassical theoretical growth model developed by Mankiw et al. (1992). They develop a model that integrates human capital and provides opportunities to add economic policy variables to analyze their effects on economic growth. The theoretical form of the model is as follows:

$$
Y(t)=K(t)^{\alpha} H(t)^{\beta}[A(t) L(t)]^{1-\alpha-\beta}
$$

where $Y(t)$ is the level of production, $K(t)$ is the physical capital stock, $H(t)$ is the human capital stock, $L(t)$ is the labor stock, and $A(t)$ is the level of technology in each country. Some transformations of Equation (1) with insertion of interest variables, control, and the heterogeneous characteristics of each country help in obtaining the following econometric model: 


$$
y_{i t}=\lambda_{0 i}+Z_{i t} \lambda_{1 i}+\lambda_{2 i} K O F_{i t}+\mu_{i t}
$$

where $y_{i t}$ is the GDP per capita of country $i$ at time $t, Z$ is a vector that includes all control variables including education, investment rate, population growth rate, inflation, and governance (quality of institutions), and $\mu_{i t}$ is the composite error term. KOF is the interest variable in the present study that includes de jure, de facto globalization KOF index, and their dimensions. Several panel tests were conducted to obtain appropriate estimation of model (2). Two generations of panel tests exist (Hurlin and Mignon 2007).

The choice between the generation tests will depend on the presence or absence of crosssectional dependence. Pesaran (2004) and Chudik and Pesaran (2015) have shown that there may be some unobserved common factors among the units (countries) studied that can explain their dependency relationships, that is, cross-sectional dependence. Spatial econometrics also explains these dependency relationships between units localized in space by spillover and neighborhood effects (LeSage and Pace 2009). Pesaran (2006) and Pesaran and Chudik (2015) proved that ignorance or inappropriate treatment of this cross-sectional dependence leads to biased and inconsistent estimators. To identify this spatial dependence, the Pesaran (2006) pre-estimation test is used. This test computes a statistic (CD), which under the null hypothesis of independence (no cross-sectional dependence), is distributed normally with mean 0 and variance 1 . Implementation of the test confirms the presence of cross-sectional dependence since the probabilities ( $p$-value) of CD statistics are less than $5 \%$, leading to the rejection of the null hypothesis (Appendix). The presence of crosssectional dependence invalidates the power of first-generation unit root (or stationarity) and cointegration tests that measured independence between the units studied (Pesaran 2007, Persyn and Westerlund 2008, Shariff and Hamzah 2015) ${ }^{1}$.

To test the variables unit root, the second-generation test developed by Paseran (2007) is used. This test considers any kind of dependence and the heterogeneous characteristics of the units concerned. The test reports a CIPS statistic that, under the null hypothesis of unit root, is normally distributed with mean 0 and variance 1 . The test reveals the presence of unit root for four explanatory variables. The other variables including the dependent variable are stationary, which have their CIPS lower than the critical CIPS proposed at the thresholds of $1 \%, 5 \%$, and $10 \%$. Nonstationary variables, on the other hand, have their CIPS higher than the critical CIPS. Absence of unit root for the dependent variable precludes any possibility of a long-term relationship and avoids implementing the Westerlund (2008) cointegration test. Implementation of this second-generation test confirms model (2) as the estimable model. Several estimation strategies are envisaged depending on the presence of crosssectional dependence. In the case of independence, that is, no cross-sectional dependence, one can use fixed-effects or random-effects estimations according to Fisher, BreuschPagan, and Hausmann specification tests. The presence of cross-sectional dependence leads to the bias and inconsistence of fixed- and random-effects models results and call for new methodologies.

A spatial weighting matrix (Anselin 2013, Elhorst 2014) is used to deal with cross-

${ }^{1}$ For unit root and cointegration tests, for example Choi (2001); Levin, Lin and Chu (2002) and Im, Pesaran and Shin (2003). 
sectional dependence. The weighting matrix is constructed using units of proximity or some functions of the distance between them. Corrado and Fingleton (2012) show that this approach leads to the misspecification if the cross-sectional dependence is not reducing with distance. An alternative is to model cross-sectional dependence as a function of time-specific common factors (Pesaran and Smith 1995, Pesaran 2006) and use the common correlated effects estimator as proposed by Pesaran (2006). This popular approach in the macro-panel literature (Eberhardt and Teal 2011) generally leads to misspecification by considerably reducing the number of parameters to be estimated. The Feasible Generalized Least squares (FGLS) method proposed by Parks (1967) is the alternative method to solve effectively the problem of cross-sectional dependence in panel data. This approach incorporates crosssectional dependence when completing the variance-covariance matrix and solves the problem of heteroscedasticity and errors autocorrelation (Moundigbaye et al. 2017). The present study uses the latter approach for effectively avoiding problems of heteroscedasticity, errors autocorrelation, and mainly the cross-sectional dependence problem. Park estimation approach offers another major advantage associated with possible treatment of outliers. A literature review proposes robust methodological approaches to overcome this problem. These robust methodologies include Generalized Least Squares Method. According to De Gruttola et al. (1987), Generalized Least Squares Method, which weights individual observations, yields an estimator less affected by outliers. Therefore, the results of the present study are based on Park methodology (FGLS), which are least influenced by outliers. In addition, other existing robust methodologies do not solve spatial dependence problem, which is a concern in the present study.

\section{Data and Variables Description}

To analyze the effect of globalization on economic growth, the study uses annual data for 40 SSA countries from 1980 to 2015. Countries and period choice is based on data availability, especially on dependent and globalization variables. The study uses GDP per capita growth as a dependent variable to measure economic growth. Data on GDP per capita growth is obtained from "World Development Indicator (WDI)." Some commonly used variables in growth equations also control for the study estimations.

\section{A. Interest explanatory variables: KOF indices of de jure and de facto globalization and their dimensions}

In the present study, the KOF index is used to measure globalization. This index includes all dimensions of globalization, that is, economic, political, and social. It also includes a large set of panel data comprising more than 200 countries and across 1970 2015. These data are easily accessible and can be updated annually. In its 2018 revised version, this index distinguishes between de facto to de jure globalization. While de facto globalization 
considers variables that represent real flows or activities, de jure globalization focuses on the policy variables or institutions that orient actual flows and activities (Gygli et al. 2018) 2 . The present study makes this distinction for several reasons. First, as highlighted by Quinn et al. (2011), effects of globalization on economic growth can depend on the desirability of a de facto or de jure measure. This distinction is also important because of the substantial gap between de facto and de jure measures of globalization, as in the case of rigorous measures in theory but ineffective in practice (Kose et al. 2009).

The KOF index of globalization, whether de jure or de facto, is obtained from three subindices that are relate to the economic, political, and social dimensions of globalization. Each subindex includes several indicators. In the 2018 revised version of the KOF index, the de facto economic globalization subindex includes both trade (trade flows as a percentage of GDP) and financial indicators. Financial indicators include the sum of stocks of assets and liabilities of FDI, portfolio investment (as a percentage of GDP), and the sum of primary income and cross-border labor and capital income (as a percentage of GDP). The subindex of de facto social globalization is obtained by considering interpersonal, informational, and cultural indicators. Interpersonal indicators include international voice traffic, financial transfers, tourism, and the share of foreign-born. Informational indicators include the stock of patent applications filed by nonresidents, the total of incoming and outgoing foreign students, and the export of high-technology products. Finally, cultural indicators are measured by the number of McDonald's restaurants, IKEA stores, and cultural goods trade and personal, cultural, and recreational services. De facto political globalization subindex combines the amount of participation in United Nations peacekeeping missions, the number of embassies, and the number of NGOs in a country.

De jure economic, political, and social globalization subindices emanate from some specific indicators. De jure economic globalization subindex is built using de jure commercial and financial globalization indicators. De jure commercial indicators are related to the average of prevalent nontariff barriers and procedural costs based on the Doing Business report and trade taxes as measured by international trade taxes as a percentage of total income. Financial globalization indicators include IMF Chinn-Ito Index, Jahan and Wang (2016) Index, and restrictions on investment, including the prevalence of foreign ownership and regulation related to international capital flows. ${ }^{3}$ De jure social globalization arises from de jure interpersonal, informational, and cultural globalization indicators. De jure interpersonal indicator emphasizes the number of users of fixed and mobile phones, number of airports hosting international flights, and the freedom of foreigners to visit the country. De jure informational globalization indicators comprise the number of televisions and Internet users per household, relevance of Internet use, and press freedom. De facto cultural globalization indicators involve government's expenditure on education as a percentage of GDP, the gender parity index of primary school enrollment, and civil liberty index. De jure political globalization subindex includes the number of multilateral treaties signed

\footnotetext{
${ }^{2}$ For detail on KOF revised index (Gygli et al. 2018).

${ }^{3}$ The IMF Chinn-Ito index is an index measuring a country's degree of capital account openness. Chinn and Ito (2007): http://www.web. pdx.edu/ ito/kaopen_Chinn-Ito_hi0523.pdf.
} 
by the country since 1945 and the number of memberships to international organizations. Globalization indices, whether de jure or de facto, and subindices are scale variables ranging from 1 to 100. The value 1 indicates the minimum globalization state and the value 100 the maximum of globalization state. Trends on globalization variables are provided in appendix.

\section{B. Control variables}

The study estimations are controlled by some explanatory variables that potentially influence economic growth, which then includes investment. Both theoretical and empirical literatures consider investment as a direct indicator of physical capital accumulation, as well as an indicator of economic infrastructure development (Zahonogo 2016). This variable is captured in the present study by gross fixed capital formation (as a percentage of GDP). Human capital is also introduced as a control variable. This variable is identified in the literature as an indicator of technology accumulation (Benhabib and Spiegel 2005, Borensztein et al. 1997). Human capital is measured by the gross secondary school enrollment rate and the population growth. This rate by definition can be greater than $100 \%$. Gross enrollment ratio is defined as the total number of students, regardless of age, enrolled in a particular level of education, measured in proportion to the age group corresponding to that level. Its value close to or greater than $100 \%$, which indicates that a country is, in principle, able to support the entire school population of a given level, but it does not indicate the number of students already enrolled at this level. It is observed that, unlike the gross enrollment rate, the net enrollment rate for a given level never exceeds 100\% (Maligalig et al. 2010). ${ }^{4}$ Effect of inflation on economic growth has been debated in the literature (Egbetunde and Akinlo 2015, Gurgsul and Lach 2014, Dornbusch et al. 1996). This variable is also considered in the present study and is measured by the annual index of consumer prices. The quality of institutions or democracy framework also affects economic growth (Acemoglu and Robinson 2012). This institutional or democratic environment is considered by introducing the "polity 2" variable taken from "Polity IV." It is the scores variable reflecting the state of the diet in each country. These scores range from -10 (highly autocratic regime) to +10 (highly democratic regime). To avoid the drawback of missing data, we imputed the latter by using the linear interpolation method, which is an efficient method of processing missing data (Gygli et al. 2018). 
Table 1. Source, definition, and descriptive statistics of the variables

\begin{tabular}{|l|l|c|c|c|c|}
\hline \multicolumn{1}{|c|}{ Variables } & Definition & Average & Min & Max & Source \\
\hline gdp_pc_growth & GDP per capter growth & 1.215 & -47.81 & 140.5 & WDI \\
\hline kofgi & KOF overall globalization & 41.01 & 18.27 & 70.03 & KSEI \\
\hline kofgidf & KOF de facto globalization & 40.94 & 15.09 & 70.74 & KSEI \\
\hline kofgidj & KOF de jure globalization & 41.12 & 15.49 & 78.99 & KSEI \\
\hline kofecgi & $\begin{array}{l}\text { KOF economic } \\
\text { globalization }\end{array}$ & 40.95 & 10.49 & 82.38 & KSEI \\
\hline kofecgidf & $\begin{array}{l}\text { KOF economic de facto } \\
\text { globalization }\end{array}$ & 47.77 & 8.562 & 92.52 & KSEI \\
\hline kofecgidj & $\begin{array}{l}\text { KOF economic de jure } \\
\text { globalization }\end{array}$ & 33.56 & 9.284 & 76.89 & KSEI \\
\hline kofsogi & KOF social globalization & 30.99 & 6.857 & 73.67 & KSEI \\
\hline kofsogidf & $\begin{array}{l}\text { KOF social de facto } \\
\text { globalization }\end{array}$ & 26.20 & 5.679 & 69.56 & KSEI \\
\hline kofsogidj & $\begin{array}{l}\text { KOF social de jure } \\
\text { globalization }\end{array}$ & 35.45 & 5.652 & 83.44 & KSEI \\
\hline kofpogi & KOF political globalization & 50.41 & 11.54 & 89.03 & KSEI \\
\hline kofpogidf & $\begin{array}{l}\text { KOF political de facto } \\
\text { globalization }\end{array}$ & 46.86 & 12.85 & 94.96 & KSEI \\
\hline kofpogidj & $\begin{array}{l}\text { KOF political de jure } \\
\text { globalization }\end{array}$ & 53.96 & 6.902 & 87.13 & KSEI \\
\hline pop_growth & Population growth & 2.655 & -6.185 & 7.918 & WDI \\
\hline educ_secgross & Education & 32.02 & 2.484 & 116.0 & WDI \\
\hline $\begin{array}{l}\text { gross_frixed_ } \\
\text { capgdp }\end{array}$ & Gross fixe capital formation & 20.78 & -2.424 & 219.1 & WDI \\
\hline inf_cons_price & Inflation & 65.62 & -35.84 & 24,411 & WDI \\
\hline polity_2 & Institutions quality & -0.974 & -10 & 10 & Polity IV \\
\hline
\end{tabular}

(Note) KSEI means KOF Swiss Economic Institute 


\section{Results and Discussion}

The study results are based on the Parks (1967) estimation approach. The correlation matrix is also used to display collinearity diagnosis test between interest explanatory variables. Correlation matrix shows high and significant correlation coefficients between these variables (Appendix or the test). This attests the presence of collinearity (Appendix) between interest explanatory variables, therefore, separate estimations are run, each including one interest explanatory variable.

Table 2 shows the results of overall effects of globalization and its dimensions on economic growth without distinguishing between de jure and de facto aspects. The chi-square $\left(\mathrm{Chi}^{2}\right)$ statistic of these four estimations are high and significant at $1 \%$, reflecting the global estimation significance. Column (1) helps in assessing the overall globalization effect, while columns (2), (3), and (4) examine, respectively, economic, social, and political globalization effects. Coefficients related to globalization variables in columns (1), (2), and (3) are positive and significant at $1 \%$. These results prove that overall globalization and its economic and social dimensions positively affect economic growth in SSA countries. A 1.0 percentage point improvement in the KOF overall globalization index increases economic growth (per capita GDP growth rate) in SSA countries by 0.015 percentage point. Such improvement for the KOF indices of economic and social globalizations generates an economic growth of 0.04 and 0.013 percentage points, respectively. Political globalization (Column 4) has a significant and negative impact on the economic growth of SSA countries. The coefficient $(-0.012)$ associated with this variable is negative and significant at $1 \%$. The study results corroborate with Dreher (2006), Rao and Vadlamannati (2011), and Gurgul and Lach (2014). However, the coefficients appear smaller than those of the previous studies and probably for the consideration of cross-sectional and temporal dependencies and the study period included. 
Table 2. Effects of globalization and its dimensions on economic growth

(GDP per capita growth rate)

\begin{tabular}{|c|c|c|c|c|}
\hline Variables & (1) & (2) & (3) & (4) \\
\hline kofgi & $\begin{array}{c}0.015 * * * \\
(0.006)\end{array}$ & & & \\
\hline Pop_growth & $0.243 * * *$ & $0.424 * * *$ & $0.305 * * *$ & $0.481 * * *$ \\
\hline educ_secgross & $0.011 * * *$ & $0.010 * * *$ & $0.010 * * *$ & $0.021 * * *$ \\
\hline gross_frixed_capgdp & $\begin{array}{c}0.150^{* * *} \\
(0.005)\end{array}$ & $0.146^{* * *} *$ & $0.151 * * *$ & $0.157 * * *$ \\
\hline infl_cons_price & $-0.000 * * *$ & $-0.000^{* * *}$ & $-0.000^{* * *}$ & $-0.000^{* * *}$ \\
\hline polity_2 & $0.083^{* * *}$ & $0.081 * * *$ & $0.082 * * *$ & $0.101 * * *$ \\
\hline kofecgi & & $\begin{array}{c}0.040 * * * \\
(0.005)\end{array}$ & & \\
\hline$k o f s o g i$ & & & $0.013^{* * *}$ & \\
\hline kofpogi & & & & $-0.024 * * *$ \\
\hline Constant & $\begin{array}{c}-6.716^{* * *} \\
(0.458)\end{array}$ & $\begin{array}{c}-10.346^{* * *} \\
(0.561) \\
\end{array}$ & $\begin{array}{c}-7.438^{* * *} \\
(0.429) \\
\end{array}$ & $\begin{array}{c}-9.069^{* * *} \\
(0.721)\end{array}$ \\
\hline Observations & 1,440 & 1,440 & 1,440 & 1,440 \\
\hline Number of countries & 40 & 40 & 40 & 40 \\
\hline Wald $\left(\mathrm{Chi}^{2}\right)$ & $2018 * * *$ & $3316 * * *$ & $2117 * * *$ & $1484 * * *$ \\
\hline Wooldridge Test for Auto. & $8.152 * * *$ & $8.096 * * *$ & $8.077 * * *$ & $8.199 * * *$ \\
\hline LM Test for Hetero. & $903.848 * * *$ & $900.221 * * *$ & $903.685^{* * *}$ & $906.915^{* * *}$ \\
\hline
\end{tabular}

(Note) $* * *, * *$ and $*$ indicate significance at $1 \%, 5 \%$ and $10 \%$ respectively. Standard deviations in parentheses.

Table 3 shows the effect of de jure globalization and its components on economic growth. It shows high and significant chi-square $\left(\mathrm{chi}^{2}\right)$ statistics, indicating the overall significance of estimations. Column (1) in Table 3 shows that de jure globalization promotes economic growth in SSA countries. This implies that governments' policies and legislation on globalization can contribute to enhance economic growth in these countries. Columns (2) and (3), which report the effects of de jure economic and social globalizations, respectively, indicate that the theoretical government orientations related to the economic and social globalizations support economic growth. Indeed, the coefficients of both variables are positive and significant at $1 \%$. For example, the improvement of the KOF index of de jure economic globalization by 1 unit boosts the growth (per capita GDP growth rate) by nearly 
0.03 units. Such improvement for de jure social globalization KOF index increases the per capita GDP growth rate by about 0.022 unit. De jure political globalization does not affect economic growth in SSA countries. The coefficient associated with this variable is positive but not significant.

Table 3. Effects of de jure globalization and its dimensions on economic growth

(GDP per capita growth rate)

\begin{tabular}{|c|c|c|c|c|}
\hline Variables & (1) & (2) & (3) & (4) \\
\hline kofgidj & $0.032 * * *$ & & & \\
\hline pop_growth & $0.284 * * *$ & $0.341 * * *$ & $\begin{array}{c}0.311 * * * \\
(0.032)\end{array}$ & $0.297 * * *$ \\
\hline educ_secgross & $\begin{array}{l}0.008 * * \\
(0.003)\end{array}$ & $\begin{array}{c}0.013 * * * \\
(0.003)\end{array}$ & $0.005 * *$ & $\begin{array}{c}0.016^{* * *} \\
(0.002)\end{array}$ \\
\hline gross_frixed_capgdp & $0.153^{*} * *$ & $0.153 * * *$ & $0.149 * * *$ & $0.156^{* * *}$ \\
\hline infl_cons_price & $-0.000 * * *$ & $-0.000 * * *$ & $-0.000 * * *$ & $-0.000 * * *$ \\
\hline polity_2 & $0.072 * * *$ & $0.080 * * *$ & $0.067 * * *$ & $0.086 * * *$ \\
\hline kofecgidj & & $\begin{array}{c}0.028 * * * \\
(0.004)\end{array}$ & & \\
\hline kofsogidj & & & $\begin{array}{c}0.022 * * * \\
(0.004)\end{array}$ & \\
\hline kofpogidj & & & & $\begin{array}{l}-0.001 \\
(0.003)\end{array}$ \\
\hline Constant & $\begin{array}{c}-7.948^{* * *} \\
(0.622) \\
\end{array}$ & $\begin{array}{c}-8.529 * * * \\
(0.569)\end{array}$ & $\begin{array}{c}-7.751 * * * \\
(0.438)\end{array}$ & $\begin{array}{c}-7.109 * * * \\
(0.700)\end{array}$ \\
\hline Observations & 1,440 & 1,440 & 1,440 & 1,440 \\
\hline Number of countries & 40 & 40 & 40 & 40 \\
\hline Wald $\left(\mathrm{Chi}^{2}\right)$ & $2831 * * *$ & $3092 * * *$ & $2129 * * *$ & $1263 * * *$ \\
\hline Wooldridge Test for Auto. & $8.281 * * *$ & $8.221 * * *$ & $8.149 * * *$ & $8.313 * * *$ \\
\hline LM Test for Hetero. & $902.867 * * *$ & $906.763 * * *$ & $901.8 * * *$ & $903.921 * * *$ \\
\hline
\end{tabular}

(Note) $* * *, * *$ and $*$ indicate significance at $1 \%, 5 \%$ and $10 \%$ respectively. Standard deviations in parentheses.

Table 4 discusses the effects of de facto globalization and its dimensions on economic growth. Similar to the previous estimations, those in Table 4 are also significant. Columns (1) and (4) in Table 4 show that the de facto globalization and its political dimension worsen economic growth in SSA countries. Increasing the KOF index of de facto political globalization by 10 percentage points leads to a decrease in the GDP per capita growth 
rate by about 0.3 percentage points. The economic dimension of de facto globalization (Column 2), on the other hand, improves economic growth in SSA countries. De facto social globalization has no effect on economic growth. Comparison between the results of Tables 4 and 3 suggests that globalization policies and institutions that should facilitate pragmatic activities and flows have not been effective, probably because of implementation and monitoring difficulties or implementation inadequacy of these measures in practice. Indeed, if de jure globalization boosts economic growth, while de facto globalization damages economic growth, it likely implies that the globalization legislation enforced by SSA governments does not bear the expected effects regarding globalization in practice.

Table 4. Effects of de facto globalization and its dimensions on economic growth

(GDP per capita Growth Rate)

\begin{tabular}{|c|c|c|c|c|}
\hline Variables & (1) & (2) & (3) & (4) \\
\hline Kofgidf & $\begin{array}{c}-0.005^{* *} \\
(0.005)\end{array}$ & & & \\
\hline pop_growth & $0.288^{* * *}$ & $0.384 * * *$ & $\begin{array}{c}0.298^{*} * * \\
(0.042)\end{array}$ & $0.591 * * *$ \\
\hline educ_secgross & $0.017 * * *$ & $0.014 * * *$ & $0.014 * * *$ & $0.023 * * *$ \\
\hline gross_frixed_capgdp & $\begin{array}{c}0.154 * * * \\
(0.006)\end{array}$ & $0.150 * * *$ & $\begin{array}{c}0.154 * * * \\
(0.006)\end{array}$ & $0.157 * * *$ \\
\hline infl_cons_price & $-0.000 * * *$ & $-0.000 * * *$ & $-0.000^{*} * *$ & $-0.000^{* * *}$ \\
\hline polity_2 & $\begin{array}{l}0.094 * * * \\
(0.010)\end{array}$ & $\begin{array}{c}0.092 * * * \\
(0.012)\end{array}$ & $\begin{array}{c}0.085 * * * \\
(0.011)\end{array}$ & $0.107 * * *$ \\
\hline kofecgidf & & $0.017 * * *$ & & \\
\hline kofsogidf & & & $\begin{array}{c}0.006 \\
(0.006)\end{array}$ & \\
\hline kofpogidf & & & & $-0.030 * * *$ \\
\hline Constant & $\begin{array}{c}-6.795 * * * \\
(0.661)\end{array}$ & $\begin{array}{c}-9.140^{* * *} \\
(0.534)\end{array}$ & $\begin{array}{c}-7.286^{* * *} \\
(0.703)\end{array}$ & $\begin{array}{c}-10.631 * * * \\
(0.750)\end{array}$ \\
\hline Observations & 1,440 & 1,440 & 1,440 & 1,440 \\
\hline Number of countries & 40 & 40 & 40 & 40 \\
\hline Wald $\left(\mathrm{Chi}^{2}\right)$ & $1202 * * *$ & $3039 * * *$ & $1282 * * *$ & $1264 * * *$ \\
\hline Wooldridge Test for Auto. & $8.139 * * *$ & $8.064 * * *$ & $8.078 * * *$ & $8.218 * * *$ \\
\hline LM Test for Hetero. & $909.107 * * *$ & $898.493 * * *$ & $903.889 * * *$ & $908.557 * * *$ \\
\hline
\end{tabular}

(Note) $* * *, * *$ and $*$ indicate significance at $1 \%, 5 \%$ and $10 \%$ respectively. Standard deviations in parentheses. 
Moreover, de jure and de facto economic globalization outbid economic growth but with a low coefficient for the latter. Similar effects of both economic globalization aspects may imply that economic globalization policies and institutions of SSA countries have their expected effects. De jure social globalization supports economic growth, while de facto social globalization has no effect on the latter. This result shows that the efforts to materialize policies and institutions targeting social globalization are limited in producing their expected effects. Finally, de jure political globalization does not affect economic growth, while de facto political globalization has a negative impact on economic growth in SSA countries. The study result implies that political globalization directives and institutions in SSA countries are poorly designed. The repercussions of this misconception of policies and institutions are translated to harmful effects on the macroeconomic variables such as economic growth in SSA countries. The study results are partly highlighted by Gygli et al. (2018), who reported that SSA is one of the regions with low de jure and de facto globalization KOF indices that can negatively affect its development. These effects pointed out between de jure and de facto aspects of globalization support the study by Quinn et al. (2011), which states the decision to use de facto or de jure measures of globalization can lead to systematically different conclusions in the association between globalization and economic growth.

Finally, the control variables have their expected effects. Secondary education as a variable to capture human capital has a positive and significant coefficient for all estimations. Dreher (2006) and Gurgul and Lach (2014) found that inflation erodes money purchasing power, which negatively affects economic growth. The investment regarded in the literature as economic growth engine proves to be true for all estimations. The effect of the coefficient of the variable used to assess governance framework or quality of institutions on growth remains positive, denoting that good governance (good institutions) enhances economic growth.

\section{Conclusion and Recommendations}

The present study examines the effects of globalization and its dimensions on economic growth in SSA by distinguishing between de jure and de facto aspects of globalization and underlining effective resolution of cross-sectional dependence. Panel second-generation tests are used to diagnose cross-sectional dependence, unit root, and cointegration of variables. The methodology by Parks (1967) helps in tackling the problems of spatial dependence, heteroscedasticity, and errors autocorrelation. The study finds that overall globalization boosts economic growth in SSA countries. However, distinction between de jure and de facto aspect reveals a positive economic growth effect of de jure globalization, while de facto aspect harms economic growth. Among its many dimensions, the study shows that de jure and de facto economic globalization strengthens economic growth in SSA countries. De jure social globalization promotes economic growth, while de facto social globalization does not affect growth. The study also finds that de jure political globalization has no effect on economic growth, while de facto political globalization hinders growth. 
According to the present study, globalization is a lever for economic growth in SSA countries. The study also discovers rigidness in implementation of policies and institutions that govern globalization in SSA countries. First, SSA countries need to reconsider their orientations of globalization economic policies, especially political and social globalization, in order to drive economic growth. Second, these countries must rigorously supervise implementation of globalization policies and institutions in order to be effective or for de facto globalization actions to reflect de jure globalization actions. Coordination of globalization economic policies and its multiple dimensions to avoid conflict in effects is also essential.

Received 11 December 2018, Revised 26 January 2019, Accepted 31 January 2019 


\section{References}

Acemoglu, D., Naidu, S., Restrepo, P., and Robinson, J. A. "Democracy does cause growth." National Bureau of Economic Research, No. w20004 (2014).

Acemoglu, D., Johnson S., and Robinson, J. A. "Institutions as a fundamental cause of longrun growth." Handbook of economic growth, 1, (2006): 385-472.

Aker, J. C., and Mbiti I. M. "Mobile phones and economic development in Africa." Journal of Economic Perspectives, 24(3) (2010): 207-32.

Ajayi, S. I. “Globalisation and Africa.” Journal of African Economies 12 (2003): 120-150.

Alesina, A., Spolaore, E., and Wacziarg, R. "Economic integration and political disintegration." American Economic Review 90(5) (2000): 1276-1296.

Almas, H. and Sangchoon, L. "The relationship between globalization, economic growth and income inequality." Journal of Globalization Studies 1(2) (2010).

Almeida, R., and Fernandes, M. A. "Openness and technological innovations in developing countries: evidence from firm-level surveys." The Journal of Development Studies 44(5) (2008): 701-727.

Anselin, L., Le Gallo, J., and Jayet, H. "Spatial panel econometrics. In The econometrics of panel data. ”Springer, Berlin, Heidelberg (2008): 625-660.

Anselin, L. "Spatial econometrics: methods and models"Springer Science \& Business Media." (2013): Vol. 4

Baldwin, R., Braconier, H., and Forslid, R "Multinationals, endogenous growth, and technological spillovers: theory and evidence." Review of International Economics 13(5) (2005): 945-963.

Barro, R. J., and Sala-I-Martin, X. "Technological Diffusion, Convergence, and Growth." Journal of Economic Growth 2 (1) (1997): 2-26.

Barry, H. "Globalization and Economic Growth in Sub-Saharan Africa." Gettysburg Economic Review 4(1) (2010): 4.

Baumont, C., Ertur, C., and Le Gallo, J. "Spatial convergence clubs and the European regional growth process, 1980-1995. In European regional growth. ” Springer, Berlin, Heidelberg (2003): 
$131-158$

Benhabib, J., and Spiegel, M. M. "Human capital and technology diffusion." Handbook of economic growth (2005): 935-966.

Bivand, R., and Piras, G. "Comparing implementations of estimation methods for spatial econometrics.”American Statistical Association (2015).

Borensztein, E., De Gregorio, J. and Lee, J. W. "How does foreign direct investment affect economic growth?” Journal of international Economics 45(1) (1998): 115-135.

Chudik, A., \& Pesaran, M. H "Common correlated effects estimation of heterogeneous dynamic panel data models with weakly exogenous regressors." Journal of Econometrics 188(2) (2015): 393-420.

Clark, W. C. "Governance in a Globalizing World, Chapter Environmental globalization." Brookings Institution Press (2000): 86-108.

Coe, D. T., and Helpman, E. "International R\&D spillovers". European economic review 39(5) (1995): 859-887.

Corrado, L., and Fingleton, B “Where is the economics in spatial econometrics?" Journal of Regional Science 52(2) (2012): 210-239.

De Gruttola, V., Ware, J. H., and Louis T. A. "Influence analysis of generalized least squares estimators". Journal of the American Statistical Association 82(399) (1987): 911-917.

Dreher, A. "Does globalization affect growth? Evidence from a new index of globalization." Applied Economics 38(10) (2006): 1091-1110.

Dreher, A., Gaston, N., and Martens, P. "Measuring globalization: Gauging its consequences" Springer Science and Business Media, (2008).

Dreher, A., Gaston, N., and Martens, P. "Measuring globalization opening the black box. A critical analysis of globalization indices". Journal of Globalization Studies, 1(1) (2010).

Egbetunde, T., and Akinlo, A. E. "Financial globalization and economic growth in SubSaharan Africa: Evidence from panel cointegration tests." African Development Review, 27(3) (2015): 187-198.

Elhorst, J. P. "Spatial panel data models. In Spatial econometrics. ”Springer, Berlin, Heidelberg, (2014): 37-93. 
Grossman, G. M., and Helpman. E. "Innovation and growth in the global economy." MIT press, (1993).

Gurgul, H., and Lach, L. "Globalization and economic growth: Evidence from two decades of transition in CEE.” Economic Modelling 36 (2014): 99-107.

Gygli, S, Haelg, F. and Sturm, J. E. “The KOF Globalisation Index-Revisited.” KOF Working Papers, (2018).

Khaliq, A., and Noy, I. "Foreign direct investment and economic growth: Empirical evidence from sectoral data in Indonesia." Journal of Economic Literature 45(1) (2007): 313-325.

Kilic, C. "Effects of Globalization on Economic Growth: Panel Data Analysis for Developing Countries." Petroleum-Gas University of Ploiesti Bulletin, Technical Series, (2015), http:// www.upg-bulletin-se.ro/archive/2015-1/1.Kilic.pdf

LeSage, J., and Pace, R. K. "Introduction to spatial econometrics. Chapman and Hall/CRC." (2009), https://journals.openedition.org/rei/pdf/3887.pdf.

LeSage, J., and Pace, R. K. "Interpreting spatial econometric models. In Handbook of regional science. ”Springer, Berlin, Heidelberg, (2014).

Levine, R., and Renelt, D. "A sensitivity analysis of cross-country growth regressions." The American economic review (1992): 942-963.

Majidi, A. F. "Globalization and Economic Growth: The Case Study of Developing Countries." Asian Economic and Financial Review 7(6) (2017): 589.

Mankiw, N. G., Romer, D., and Weil, D. N. "A contribution to the empirics of economic growth.” The quarterly journal of economics 107(2) (1992): 407-437.

Meissner, C. M. "Growth from globalization? A view from the very long run.” In Handbook of economic growth, Elsevier, (2014).

Moghaddam, A. A., and Redzuan, M. R. "Globalization and economic growth: A case study in a few developing countries (1980-2010).” Research in World Economy 3(1) (2012):54.

Moundigbaye, M., Rea, W. S.and Reed, W. R. "Which panel data estimator should I use?: A corrigendum and extension." Economics Discussion Papers, Kiel Institute for the World Economy, (2017).

Musila, J. W., and Yiheyis, Z. "The impact of trade openness on growth: The case of Kenya." 
Journal of Policy Modeling 37(2) (2015): 342-354.

Nahavandian, M. \& Ghanbari, M. F. A. “We and globalization.” Tehran: Institute for Humanities and Cultural Studies, (2004).

Norris, P. "Governance in a Globalizing World, chapter Global governance and cosmopolitan citizens.” Brookings Institution Press. (2000).

Nye, J. S., and Donahue, J. D. "Governance in a globalizing world." Brookings Institution Press, (2000).

Nyirenda-Jere, T., and Biru, T. "Internet development and Internet governance in Africa." Internet Society, (2015).

Olimpia, N., and Stela, D. "Impact of Globalisation on Economic Growth in Romania: An Empirical Analysis of Its Economic, Social and Political Dimensions." Studia Universitatis Vasile Goldis Arad-Economics Series, (2017).

Parks, R. W. ' 'Efficient estimation of a system of regression equations when disturbances are both serially and contemporaneously correlated." Journal of the American Statistical Association 62(318) (1967): 500-509.

Persyn, D., and Westerlund, J. "Error-correction-based cointegration tests for panel data." Stata Journal 8(2) (2008): 232-241.

Pesaran, M. H. "General diagnostic tests for cross-section dependence in panels." CESifo Working Paper No. 1229, (2004), https://journals.plos.org/plosone/article/file?id=10.1371/journal.pone.0087824\&type=printable. pdf.

Pesaran, M. H. "Estimation and inference in large heterogeneous panels with a multifactor error structure." Econometrica, 74(4) (2006): 967-1012.

Pesaran, M. H. "A simple panel unit root test in the presence of cross-section dependence." Journal of applied econometrics 22(2) (2007): 265-312.

Pesaran, M. H. "Testing weak cross-sectional dependence in large panels." Econometric Reviews 34(6-10) (2015): 1089-1117.

Pesaran, M. H., and Smith, R. "Estimating long-run relationships from dynamic heterogeneous panels." Journal of econometrics 68(1) (1995): 79-113. 
Quinn, D., Schindler, M., and Toyoda, A. M. "Assessing measures of financial openness and integration." IMF Economic Review 59(3) (2011): 488-522.

Rao, B. B., and Vadlamannati, K. C. "Globalization and growth in the low-income African countries with the extreme bounds analysis." Economic Modelling 28(3) (2011): 795-805.

Rao, B. B., and Vadlamannati, K. C. "Growth effects of a comprehensive measure of globalization with country-specific time series data." Applied Economics 43(5) (2011): 551568.

Rey, S. J. "Spatial empirics for economic growth and convergence." Geographical analysis 33(3) (2001): 195-214.

Romer, P. M. “Endogenous technological change.” Journal of political Economy 98(5, Part 2) (1990): 71-102.

Samimi, P, and Jenatabadi, H. S. "Globalization and economic growth: Empirical evidence on the role of complementarities." PloS one, 9(4), e87824, (2014).

Schneider, G. E. "Globalization and the poorest of the poor: global integration and the development process in sub-Saharan Africa." Journal of economic issues 37(2) (2003): 389396.

Shariff, N. S. M., and Hamzah, N. A. "A robust Panel Unit Root Test in the Presence of CrossSectional Dependence.” Journal of Modern Applied Statistical Methods 14(2) (2015): 14.

Redding, S. "Dynamic comparative advantage and the welfare effects of trade. " Oxford economic papers 51(1) (1999): 15-39.

United Nation World Tourism Organization. “UNWTO Tourism Highlights.” (2017), http://people.unica.it/carlamassidda/files/2017/06/UNWTO_Tourism-Highlights_2017.pdf.

Wang, J. Y., and Blomström, M. "Foreign investment and technology transfer: A simple model." European economic review 36(1) (1992): 137-155.

Young, A. "Learning by doing and the dynamic effects of international trade." The Quarterly Journal of Economics 106(2) (1991): 369-405.

Zahonogo, P. "Globalization and economic growth in developing countries: evidence from Sub-Saharan Africa.” The International Trade Journal 32(2) (2018): 189-208. 
Zahonogo, P. "Trade and economic growth in developing countries: Evidence from SubSaharan Africa." Journal of African Trade 3(1-2) (2016): 41-56. 


\section{Appendix}

\section{Appendix 1: Pesaran (2006) CD test for spatial dependence}

\begin{tabular}{|c|c|c|c|}
\hline Variables & CD-statistics & $p$-value & Correlation \\
\hline$g d p$ pc growth & 18.43 & 0.000 & 0.110 \\
\hline kofgi & 150.48 & 0.000 & 0.898 \\
\hline kofgidf & 90.27 & 0.000 & 0.539 \\
\hline kofgidj & 154.34 & 0.000 & 0.921 \\
\hline kofecgi & 33.87 & 0.000 & 0.202 \\
\hline kofecgidf & 25.85 & 0.000 & 0.154 \\
\hline kofecgidj & 7.68 & 0.000 & 0.046 \\
\hline kofsogi & 154.26 & 0.000 & 0.921 \\
\hline kofsogidf & 95.98 & 0.000 & 0.573 \\
\hline kofsogidj & 155.18 & 0.000 & 0.926 \\
\hline kofpogi & 134.39 & 0.000 & 0.802 \\
\hline kofpogidf & 61.84 & 0.000 & 0.369 \\
\hline kofpogidj & 146.40 & 0.000 & 0.874 \\
\hline pop growth & 164.77 & 0.000 & 0.983 \\
\hline educ secgross & 87.91 & 0.000 & 0.525 \\
\hline gross frixed cap gdp & 24.12 & 0.000 & 0.144 \\
\hline infl cons price & 39.11 & 0.000 & 0.233 \\
\hline polity 2 & 85.76 & 0.000 & 0.512 \\
\hline
\end{tabular}

\section{Appendix 2: Pesaran (2007) CIPS unit root test}

\begin{tabular}{|c|c|}
\hline Variables & CIPS statistics \\
\hline gdp pc growth & $-5.128 * * *$ \\
\hline kofgi & $-2.888^{* * *}$ \\
\hline kofgidf & $-2.667 * *$ \\
\hline kofgidj & $-2.620 * *$ \\
\hline kofecgi & -2.479 \\
\hline kofecgidf & -2.486 \\
\hline kofecgidj & -2.470 \\
\hline$k o f \operatorname{sog} i$ & $-2.647 * *$ \\
\hline kofsogidf & $-3.109^{* * *}$ \\
\hline kofsogidj & $-2.513^{* *}$ \\
\hline kofpogi & $-2.762 * * *$ \\
\hline kofpogidf & $-2.634 * *$ \\
\hline kofpogidj & $-2.801 * * *$ \\
\hline pop growth & $-2.72 * * *$ \\
\hline educ secgross & $-3.404 * * *$ \\
\hline gross frixed cap gdp & -2.541 \\
\hline infl cons price & $-4.141 * * *$ \\
\hline polity 2 & $-3.040 * * *$ \\
\hline
\end{tabular}

(Note) $* * *, * *$ indicate significance at $1 \%, 5 \%$ respectively. 


\section{Appendix 3: Correlation matrix}

\begin{tabular}{|c|c|c|c|c|c|c|}
\hline & $k o f g i$ & Kofgidf & kofgidj & kofecgi & kofecgidf & kofecgidj \\
\hline$k o f g i$ & 1.000 & & & & & \\
\hline kofgidf & $\begin{array}{c}0.910 \\
(0.000)\end{array}$ & 1.000 & & & & \\
\hline kofgidj & $\begin{array}{r}0.925 \\
(0.000)\end{array}$ & $\begin{array}{c}0.684 \\
(0.000)\end{array}$ & 1.000 & & & \\
\hline kofecgi & $\begin{array}{c}0.688 \\
(0.000)\end{array}$ & $\begin{array}{c}0.676 \\
(0.000)\end{array}$ & $\begin{array}{c}0.590 \\
(0.000)\end{array}$ & 1.000 & & \\
\hline kofecgidf & $\begin{array}{c}0.578 \\
(0.000)\end{array}$ & $\begin{array}{c}0.698 \\
(0.000)\end{array}$ & $\begin{array}{c}0.378 \\
(0.000)\end{array}$ & $\begin{array}{c}0.878 \\
(0.000)\end{array}$ & 1.000 & \\
\hline kofecgidj & $\begin{array}{c}0.571 \\
(0.000)\end{array}$ & $\begin{array}{c}0.376 \\
(0.000)\end{array}$ & $\begin{array}{c}0.661 \\
(0.000)\end{array}$ & $\begin{array}{c}0.731 \\
(0.000)\end{array}$ & $\begin{array}{c}0.326 \\
(0.000)\end{array}$ & 1.000 \\
\hline kofsogi & $\begin{array}{c}0.826 \\
(0.000)\end{array}$ & $\begin{array}{c}0.722 \\
(0.000)\end{array}$ & $\begin{array}{c}0.789 \\
(0.000)\end{array}$ & $\begin{array}{c}0.680 \\
(0.000)\end{array}$ & $\begin{array}{c}0.575 \\
(0.000)\end{array}$ & $\begin{array}{c}0.555 \\
(0.000)\end{array}$ \\
\hline kofsogidf & $\begin{array}{c}0.680 \\
(0.000)\end{array}$ & $\begin{array}{c}0.664 \\
(0.000)\end{array}$ & $\begin{array}{c}0.586 \\
(0.000)\end{array}$ & $\begin{array}{c}0.658 \\
(0.000)\end{array}$ & $\begin{array}{c}0.597 \\
(0.000)\end{array}$ & $\begin{array}{c}0.468 \\
(0.000)\end{array}$ \\
\hline kofsogidj & $\begin{array}{c}0.844 \\
(0.000)\end{array}$ & $\begin{array}{c}0.686 \\
(0.000)\end{array}$ & $\begin{array}{c}0.854 \\
(0.000)\end{array}$ & $\begin{array}{c}0.639 \\
(0.000)\end{array}$ & $\begin{array}{c}0.514 \\
(0.000)\end{array}$ & $\begin{array}{c}0.561 \\
(0.000)\end{array}$ \\
\hline kofpogi & $\begin{array}{c}0.586 \\
(0.000)\end{array}$ & $\begin{array}{l}0.519 \\
(0.000)\end{array}$ & $\begin{array}{c}0.557 \\
(0.000)\end{array}$ & $\begin{array}{l}-0.083 \\
(0.002)\end{array}$ & $\begin{array}{l}-0.104 \\
(0.000)\end{array}$ & $\begin{array}{c}0.013 \\
(0.626)\end{array}$ \\
\hline kofpogidf & $\begin{array}{c}0.497 \\
(0.000)\end{array}$ & $\begin{array}{c}0.530 \\
(0.000)\end{array}$ & $\begin{array}{c}0.389 \\
(0.000)\end{array}$ & $\begin{array}{l}-0.109 \\
(0.000)\end{array}$ & $\begin{array}{l}-0.152 \\
(0.000)\end{array}$ & $\begin{array}{c}0.030 \\
(0.252)\end{array}$ \\
\hline kofpogidj & $\begin{array}{c}0.557 \\
(0.000) \\
\end{array}$ & $\begin{array}{c}0.385 \\
(0.000) \\
\end{array}$ & $\begin{array}{c}0.628 \\
(0.000) \\
\end{array}$ & $\begin{array}{l}-0.033 \\
(0.205) \\
\end{array}$ & $\begin{array}{l}-0.023 \\
(0.377) \\
\end{array}$ & $\begin{array}{c}-0.011 \\
(0.681) \\
\end{array}$ \\
\hline
\end{tabular}

(Note) Standard deviations in parentheses

\section{Appendix 4: Correlation matrix}

\begin{tabular}{|c|c|c|c|c|c|c|}
\hline & kofsogi & kofsogidf & kofsogidj & kofpogi & kofpogidf & kofpogidj \\
\hline kofsogi & 1.000 & & & & & \\
\hline kofsogidf & $\begin{array}{c}0.916 \\
(0.000)\end{array}$ & 1.000 & & & & \\
\hline kofsogidj & $\begin{array}{c}0.960 \\
(0.000)\end{array}$ & $\begin{array}{c}0.776 \\
(0.000)\end{array}$ & 1.000 & & & \\
\hline kofpogi & $\begin{array}{c}0.136 \\
(0.000)\end{array}$ & $\begin{array}{c}-0.044 \\
(0.093)\end{array}$ & $\begin{array}{r}0.239 \\
(0.000)\end{array}$ & 1.000 & & \\
\hline kofpogidf & $\begin{array}{c}0.078 \\
(0.003)\end{array}$ & $\begin{array}{l}-0.083 \\
(0.002)\end{array}$ & $\begin{array}{c}0.170 \\
(0.000)\end{array}$ & $\begin{array}{c}0.913 \\
(0.000)\end{array}$ & 1.000 & \\
\hline kofpogidj & $\begin{array}{c}0.174 \\
(0.000) \\
\end{array}$ & $\begin{array}{c}0.012 \\
(0.641) \\
\end{array}$ & $\begin{array}{c}0.265 \\
(0.000) \\
\end{array}$ & $\begin{array}{c}0.873 \\
(0.000)\end{array}$ & $\begin{array}{c}0.597 \\
(0.000) \\
\end{array}$ & 1.000 \\
\hline
\end{tabular}

(Note) Standard deviations in parentheses 


\section{Appendix 5: Trends of KOF de facto globalization index and its dimensions}

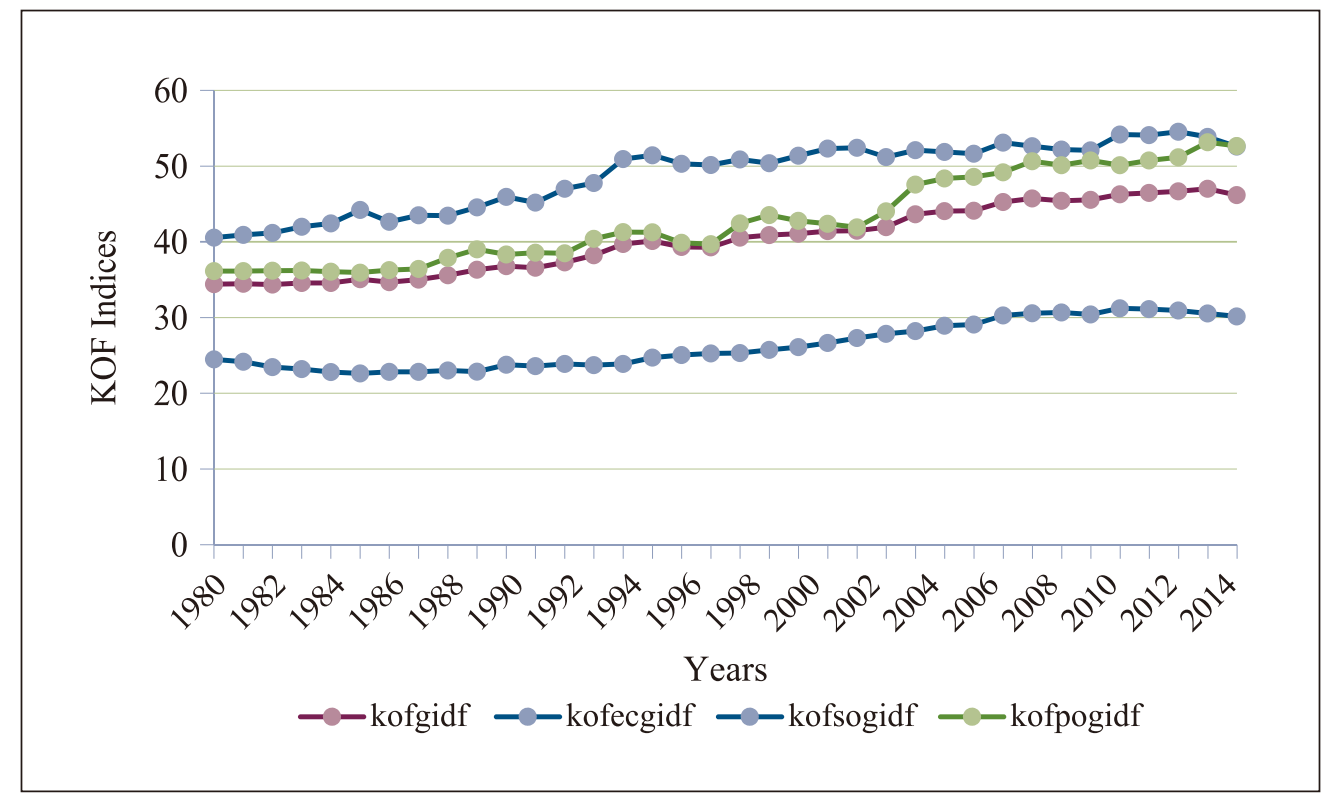

(Source) Author construction based on data from “KOF Swiss Economic Institute” (2018).

\section{Appendix 6: Trends of KOF de jure globalization index and its dimensions.}

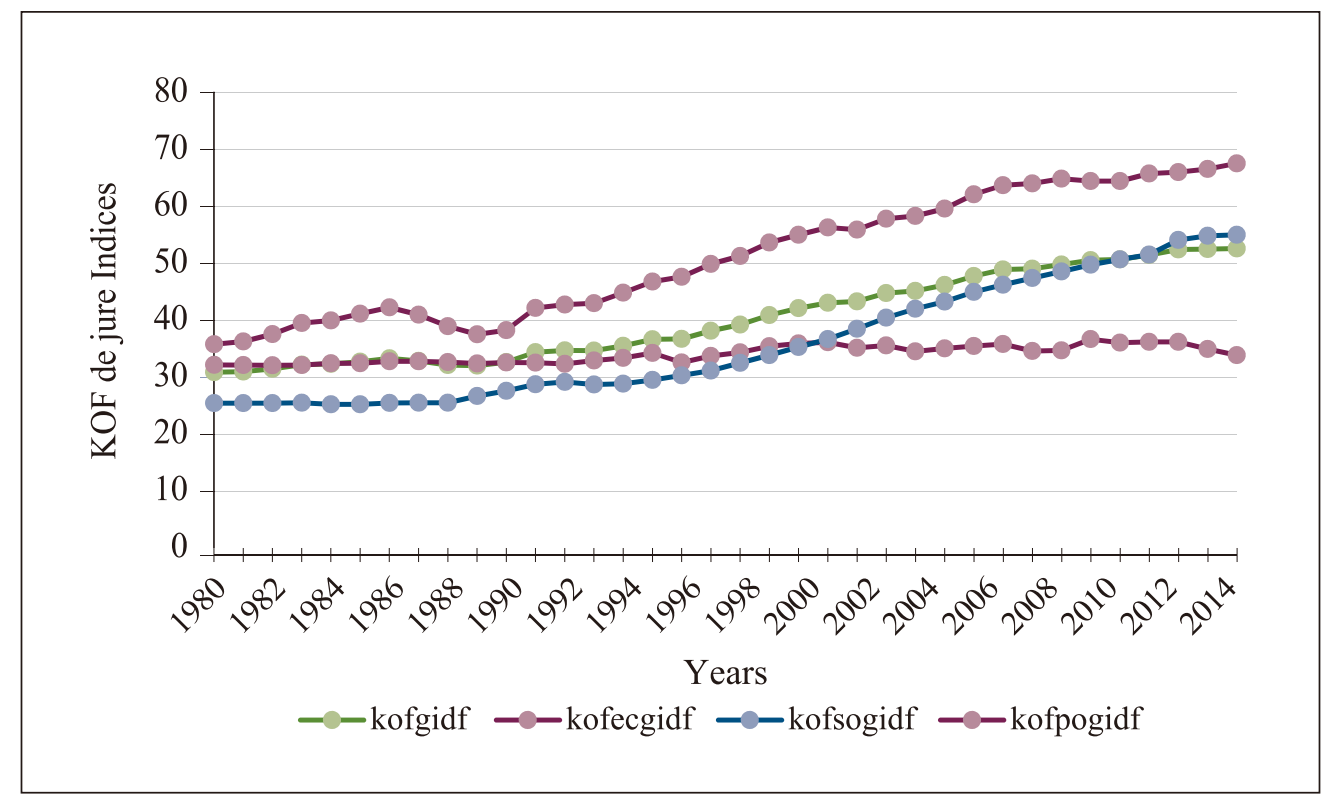

(Source) Author construction based on data from "KOF Swiss Economic Institute" (2018). 